January 2015

\title{
Professor Alan R. Bromberg's Rule 10b-5
}

Marc I. Steinberg

Southern Methodist University, Dedman School of Law

\section{Recommended Citation}

Marc I. Steinberg, Professor Alan R. Bromberg's Rule 10b-5, 68 SMU L. REV. 617 (2015)

https://scholar.smu.edu/smulr/vol68/iss3/6 


\title{
Professor Alan R. Bromberg's Rule 10b-5
}

\author{
Marc I. Steinberg*
}

I was Professor Alan Bromberg's colleague for 25 years. On several occasions, I raised the subject that the SMU Law Review should publish a Symposium Issue in his honor. He always said "no" and did so in a quick and emphatic manner. I remember the last time that I raised this subject with Alan was the only occasion that I believe he became angry with me.

I am delighted that the SMU Law Review is publishing this wonderful Symposium Issue in honor of Professor Bromberg. I regret that this Issue was not published during his lifetime. Nonetheless, I am pleased that we are honoring Alan in this very well deserved manner. I thank the Law Review and the authors for this Issue, all of whom are outstanding academicians, who have contributed to make this worthwhile project a huge success.

I was sitting in my office at the University of Maryland School of Law in the fall of 1987 when the telephone rang. Alan Bromberg was calling to invite me to interview for the Radford Chair at SMU. Having never lived in Texas or in any other locale in the South and not knowing much about SMU at the time, I accepted the opportunity. After all, if Alan Bromberg (one of the premier academicians in financial law) elected to be at SMU, that law school must have many outstanding attributes.

After a visiting appointment in fall 1988, I joined the SMU law faculty for the 1989-90 academic year. The over 25 years that have elapsed since then have been rewarding from both a personal and professional perspective. This is due in significant part to having Alan Bromberg as my valued colleague and good friend. Through both tranquil and more challenging times, Alan was a steady presence who consistently provided keen insights. I miss Alan very much. He was a truly kind, brilliant, and remarkable individual.

Alan Bromberg's scholarly achievements were impressive. In 1968, he authored the seminal treatise, Crane and Bromberg on Partnership Law. ${ }^{1}$ That treatise subsequently was revised and expanded (with his coauthor Professor Larry Ribstein) to a multi-volume work that is viewed as the premier scholarly source on the law of partnership. ${ }^{2}$

* Rupert and Lillian Radford Professor of Law, SMU Dedman School of Law.

1. Crane and Bromberg on Partnership (West Publishing Co. 1968).

2. Alan R. Bromberg and Larry E. Ribstein, Bromberg \& Ribstein on Part. NERSHIP (Little Brown \& Co. 1988) (Aspen Law \& Business 1994) (periodically updated). 
As impressive as the partnership treatise is, it was not, at least in my opinion, Alan's favorite academic endeavor. That achievement is found in Professor Bromberg's seminal treatise on SEC Rule 10b-5. That treatise, first authored in $1967,{ }^{3}$ and now expanded into an eight volume work, ${ }^{4}$ clearly is the preeminent source on the law of securities fraud-and specifically-Rule $10 \mathrm{~b}-5 .^{5}$ Through the decades, Alan toiled tirelessly on this treatise, being in his office well after midnight several days weekly-analyzing a recent court decision, SEC pronouncement, or federal statute. His "passion" for this seemingly endless demanding project was seen by his continual and vigorous scholarly regimen-arriving at his office by 9:30 staying until 5:00 (without a lunch break), returning after dinner at 7:00 and working frequently past midnight. Alan's Texas license plate said it all: the letter and numbers are "10B-5"!

Some of my more memorable securities law discussions with Alan occurred in his office shortly after a Supreme Court decision was handed down. All too often we lamented the unduly narrow approach that the Court had adopted, further confining the scope of the federal securities laws, and, in particular, Rule 10b-5. Alan was no plaintiff's lawyer. Indeed, he served as of counsel for over 30 years to Jenkens \& Gilchrist and thereafter to Hunton \& Williams. From my perspective, he believed that an appropriate balance should be struck between the ability of investors to pursue meritorious litigation and deterring the filing of vexatious lawsuits initiated primarily for their "strike suit" settlement impact.

Professor Bromberg's perspective on Rule 10b-5 likely was impacted by the state of the federal securities laws at the time he authored his treatise in 1967. For illustrative purposes, three Supreme Court decisions provide guidance. The first, Securities and Exchange Commission v. W.J. Howey Co., ${ }^{6}$ decided in 1946, expansively interpreted the term "investment contract" (within the definition of "security") to encompass the sale of citrus groves coupled with a service contract for cultivating and marketing the produce. ${ }^{7}$ In its holding, the Court, recognizing that a broad construction was consistent with the remedial intent of the federal securities laws, held that the term investment contract encompasses "a flexible

3. Alan R. Bromberg, Securities Law: Fraud: Rule 10b-5 (McGraw Hill 1967). Professor Bromberg's treatise was reviewed in 77 YALE L.J. 1585 (1968).

4. Alan R. Bromberg, Lewis D. Lowenfels, and Michael J. Sullivan, BromBerg aND Lowenfels ON SECURTIIES Fraud (2d ed. West 2012) [hereinafter BROMBERG].

5. 17 C.F.R. $\$ 240.10$ b-5.

6. 328 U.S. 293 (1946).

7. Id. at 301 (defining the term investment contract to mean "an investment of money in a common enterprise with profit to come solely from the efforts of others"). Subsequently, this test has been refined by the lower federal courts. See, e.g., Steinhardt Grp., Inc. v. Citicorp, 126 F.3d 144, 145 (3d Cir. 1997) (holding limited partner interest not a security where "the limited partner retained pervasive control over its investment in the limited partnership such that it cannot be deemed a passive investor under Howey and its progeny"); SEC v. Glenn W. Turner Enters., Inc., 474 F.2d 476, 482 (9th Cir. 1973) (stating that the key inquiry is "whether the efforts made by those other than the investor are the undeniably significant ones, those essential managerial efforts which affect the failure or success of the enterprise"). 
rather than a static principle, one that is capable of adaptation to meet the countless and variable schemes devised by those who seek the use of the money of others on the promise of profits."8

The second decision, Securities and Exchange Commission v. Ralston Purina Co., ${ }^{9}$ decided in 1953, interpreted the parameters of the Section 4(2) (now Section 4(a)(2)) private offering exemption in an investorfriendly manner. ${ }^{10}$ That exemption's availability, the Court held, turns upon "whether the particular class of persons affected needs the protection of the [Securities] Act." 11 Analyzing this inquiry, the Court focused on the subject investor (or such investor's representative) having the requisite financial sophistication and the receipt of (or access to) the type of information that would be provided in a Securities Act registration statement. ${ }^{12}$ In construing the contours of this exemption, the Court's emphasis was directed at whether the subject investor had the necessary information and sophistication to fend for himself, thereby negating the need for registration. ${ }^{13}$

From a securities litigation perspective, the third decision, J.I. Case v. Borak, ${ }^{14}$ decided in 1964 , evidenced the Supreme Court's activist approach in seeking to provide investors with adequate redress. The issue presented was whether an implied right of action should be recognized under Section 14(a) of the Securities Exchange Act and SEC Rule 14a-9. Rule $14 a-9$ prohibits the solicitation of proxies that contain any materially false or misleading statement. ${ }^{15}$ Answering this inquiry in the affirmative, the Court relied on Section 14(a)'s legislative history as well as that statute's "broad remedial purposes." 16 Focusing on the underlying objective of the proxy regimen, the Court opined: "While [Section 14(a)'s] language makes no specific reference to a private right of action, among its

8. 328 U.S. at 299. Decided the year that Professor Bromberg authored his seminal treatise, Tcherepnin v. Knight, 389 U.S. 332, 336 (1967), likewise provided a broad construction (stating that "remedial legislation should be construed broadly to effectuate its purposes").

9. 346 U.S. 119 (1953).

10. Section 4(2) (now Section 4(a)(2)) of the Securities Act of 1933 exempts from the Securities Act's registration requirements "transactions by an issuer not involving any public offering." 15 U.S.C. $\$ 77 \mathrm{~d}(\mathrm{a})(2)$.

11. 346 U.S. at 124.

12. Id. at 124-27.

13. Id. As interpreted by lower federal courts, Ralston Purina signifies that an individual's monetary wealth is not equivalent to financial sophistication. See, e.g., Doran v. Petroleum Mgmt. Corp., 545 F.2d 893, 903 (5th Cir. 1977). Nonetheless, in adopting Regulation D, which provides a safe harbor for the Section $4(a)(2)$ statutory exemption, the SEC has deemed having a specified net worth or annual income as sufficient to qualify an investor as financially sophisticated. See 17 C.F.R. $\$ \S 230.501$ (a), .505, .506 of Regulation D; Securities Act Release No. 6389 (1982). For an article criticizing the SEC's approach as being contrary to the Supreme Court's mandate in Ralston Purina, see Marc I. Steinberg, The Securities and Exchange Commission's Administrative, Enforcement, and Legislative Programs and Policies-Their Influence on Corporate Internal Affairs, 58 No. TRE DAME L. REV. 173, 209-14 (1982).

14. 377 U.S. 426 (1964).

15. 17 C.F.R. $\& 240.14 a-9$. Section $14(a)$ is the statute upon which Rule $14 a-9$ is based. 15 U.S.C. $\$ 78 \mathrm{n}(\mathrm{a})$.

16. 377 U.S. at 431. 
chief purposes is 'the protection of investors,' which certainly implies the availability of judicial relief where necessary to achieve that result."17 Going further, and invoking a pure policy rationale, the Court also opined that recognition of this implied private right of action provides a necessary supplement to the SEC's enforcement practices. ${ }^{18}$

It was with this Supreme Court precedent in focus that Professor Bromberg authored his seminal treatise in 1967. The language and tenor of these decisions portray a Supreme Court receptive to interpreting the federal securities laws in a broad manner to effectuate investor protection. With respect to the lower federal courts, litigation was proceeding under Section 10(b) and Rule 10b-5 as a private right of action under these provisions had been recognized two decades earlier. ${ }^{19}$

Three years after Professor Bromberg's Rule 10b-5 treatise was published, the Supreme Court handed down Mills v. Electric Auto-Lite Co. ${ }^{20}$ which was a continuation of the investor-friendly approach of its earlier decisions. In that decision, construing Section 14(a) and Rule 14a-9, the Supreme Court in effect dispensed with requiring a plaintiff to prove loss causation. The Court held that once "there has been a finding of materiality, a shareholder has made a sufficient showing of causal relationship between the violation and the injury for which he seeks redress if ... he proves that the proxy solicitation itself, rather than the particular defect in the solicitation materials, was an essential link in the accomplishment of the transaction."21 The Court's decision may have signaled that the federal securities laws would continue to be interpreted in a manner favorable to investors.

Five years after Mills was decided, the landscape suddenly changed. No longer was securities litigation viewed by the Supreme Court as protec-

17. Id. at 432. The era in which Borak was handed down has been called by Professor Loss as the Court's "ebullient stage" for implying private rights of action. See Louis Loss, Fundamentals of Securities Regulation 926 (2d ed. 1988).

18. 377 U.S. at 432 ; see 2 Brombero, supra note 4 , $\$ 5: 148-5: 274 ; 5$ BromBERG, supra note $4, \$ \$ 7: 96-7: 102$.

19. See Kardon v. National Gypsum Co., 69 F. Supp. 512 (E.D. Pa. 1946). This longstanding judicial recognition of an implied private right of action under Section 10(b) and Rule $10 \mathrm{~b}-5$ prompted the Supreme Court to remark that "[t]he existence of this implied remedy is simply beyond peradventure." Herman \& MacLean v. Huddleston, 459 U.S. 375, 380 (1983).

20. 396 U.S. 375 (1970).

21. Id. at 385. Today, in view of the Private Securities Litigation Reform Act of 1995 , plaintiffs invoking Section 14(a) and Rule 14a-9 must prove loss causation. See Section $21 \mathrm{D}$ (b)(4) of the Securities Exchange Act, 15 U.S.C. $\$ 78 u-4($ b)(4). In Mills, the minority shareholders had sufficient votes to affect whether the merger would be approved. The Court left open the issue whether the requisite showing of causation can be shown when insiders controlled the merger's approval (without needing the votes of the minority shareholders). Id. at 385 n.7, 386. See Schlick v. Penn-Dixie Cement Corp., 507 F.2d 374, 383 (2d Cir. 1974) (holding that minority shareholders in this situation could satisfy the causation requirement). For commentary on this issue, see Marc I. Steinberg and William A. Reece, The Supreme Court, Implied Rights of Action, and Proxy Regulation, 54 OHIO ST. L.J. 67, 101-12 (1993). For another investor-friendly decision during this era, see Affiliated Ute Citizens v. United States, 406 U.S. 128 (1972) (holding that the presence of a duty to disclose and the nondisclosure of a material fact can show causation in fact). 
tive of investor interests but as raising the specter of facilitating the filing of "vexatious" or "strike" actions. ${ }^{22}$ With some key exceptions where the Supreme Court has ruled in favor of investor interests, ${ }^{23}$ the Court's decisions have significantly narrowed the scope of the federal securities laws, and, in particular, Section 10(b) and Rule 10b-5.24

In rapid succession, the Supreme Court, reversing the appellate courts below, confined the reach of Section 10(b) and Rule 10b-5. In Blue Chip Stamps, ${ }^{25}$ decided in 1975, the Court held that the plaintiff must be a purchaser or seller of the subject securities in order to have standing to sue for damages under Section 10(b) and Rule 10b-5.26 Accordingly, those investors who elect to hold their securities after receiving false "rosy" financial information knowingly disseminated by insiders have no federal securities law private remedy. ${ }^{27}$

A year later, Ernst \& Ernst v. Hochfelder ${ }^{28}$ was decided, holding that plaintiffs, in private actions instituted for violation of Section 10(b) and Rule 10b-5, must prove a defendant's scienter (i.e., knowing or intentional misconduct) ${ }^{29}$ Reversing the Seventh Circuit, which held that negligence was the requisite culpability level, ${ }^{30}$ the Court focused on Section 10 (b)'s language, legislative history, and its relationship to the express civil remedies of the federal securities laws. ${ }^{31}$ Concluding, the Court held: "[w]hen a statute speaks so specifically in terms of manipulation and deception, and of implementing devices and contrivances-the commonly understood terminology of intentional wrongdoing-and when its history reflects no more expansive intent, we are quite unwilling to extend the scope of the statute to negligent conduct." 32 Four years later, the Su-

22. Blue Chip Stamps v. Manor Drug Stores, 421 U.S. 723, 739-41 (1975).

23. See, e.g., Halliburton Co. v. Erica P. John Fund, Inc., 134 S. Ct. 2398 (2014) (upholding the fraud on the market theory under $\S 10(b)$ ); SEC v. Edwards, 540 U.S. 389 (2004) (holding a contractual entitlement to a fixed rate of return satisfies the expectation of profit prong of the Howey test); Basic Inc. v. Levinson, 485 U.S. 224 (1988) (recognizing the fraud on the market theory to create a rebuttable presumption of reliance under $\S 10($ b)); Herman \& MacLean v. Huddleston, 459 U.S. 375 (1983) (adopting a cumulative construction of remedies under $\S 10(\mathrm{~b})$ of the Securities Exchange Act and $\S 11$ of the Securities Act); United States v. Naftalin, 441 U.S. 768 (1979) (holding that $\$ 17(a)(1)$ of the Securities Act extends to secondary market trading).

24. See discussion infra notes $25-67$ and accompanying text.

25. Blue Chip Stamps, 421 U.S. at 723.

26. Id. at 733-55 (reversing 492 F.2d 136 (9th Cir. 1973)). Professor Bromberg's treatise is cited in the Court's opinion. See 421 U.S. at 729, 735, 752 n.15.

27. As the Court recognized, among the plaintiffs barred from bringing a Section 10 (b) action due to lack of standing "are actual shareholders in the issuer who allege that they decided not to sell their shares because of an unduly rosy representation or a failure to disclose unfavorable material." 421 U.S. at 737-38.

28. 425 U.S. 185 (1976).

29. Id. at $197-215$.

30. 503 F.2d 1100 (7th Cir. 1974), rev'd, 425 U.S. 185 (1976).

31. 425 U.S. at 194-214.

32. Id. at 214. In both Blue Chip Stamps and Hochfelder, Justice Blackmun vigorously dissented. See Blue Chip Stamps, 421 U.S. at 761-62 (Blackmun, J., dissenting) ("[By] grav[ing] into stone Birnbaum's arbitrary principle of standing . . . the Court exhibits a preternatural solicitousness for corporate well-being and a seeming callousness toward the investing public quite out of keeping, it seems to me, with our own traditions and the intent 
preme Court, placing emphasis on Section 10(b)'s statutory language and its plain meaning, extended its holding in Hochfelder to the SEC..$^{33}$ In so ruling, the Court rejected the Commission's assertion that, as the statutory guardian of the investing public, it need only prove the defendant's negligence in its enforcement actions. ${ }^{34}$

A year later, in Santa $\mathrm{Fe}^{35}$ the Supreme Court, reversing the Second Circuit, ${ }^{36}$ held that Section 10(b) and Rule 10b-5 do not encompass constructive fraud or breach of fiduciary duty. Rather, a disclosure deficiency, such as a misrepresentation, must be shown. ${ }^{37}$ The Court's decision was not surprising given its holdings a short time before in Blue Chip Stamps and Hochfelder. The practical impact of the decision was to foreclose the strategy developed by the plaintiffs' bar to invoke Section 10(b) to redress corporate self-dealing and internal corporate mismanagement, thereby seeking the application of federal standards to normative fiduciary behavior. ${ }^{38}$ This effort to employ Section 10(b) and Rule $10 \mathrm{~b}-5$ as a means to implement a federal corporation law was thoroughly rejected by the Supreme Court. ${ }^{39}$

During that time period, the Supreme Court also was active in restricting the implication of private rights of action. The Court's decision in Borak,${ }^{40}$ decided just a decade earlier, was the product of a bygone era. The broad construction to implied private rights of action abruptly halted with the Supreme Court's 1975 decision in Cort v. Ash..$^{41}$ There, the Court enunciated a four-prong standard ${ }^{42}$ in ascertaining whether Congress in-

of the securities laws."); Hochfelder, 425 U.S. at 216 (Blackmun, J., dissenting) (asserting that the majority has interpreted $\S 10(\mathrm{~b})$ and Rule 10b-5 "restrictively and narrowly and thereby stultifies recovery for the victim").

33. Aaron v. Securities and Exchange Commission, 446 U.S. 680 (1980) (holding, inter alia, that scienter must be proven by the SEC in its enforcement actions for violation of $\S 10$ (b) and Rule 10b-5).

34. Id. at 691 ("In our view, the rationale of Hochfelder ineluctably leads to the conclusion that scienter is an element of a violation of $\S 10(\mathrm{~b})$ and Rule 10b-5, regardless of the identity of the plaintiff or the nature of the relief sought.") See 5 BROMBERG, supra note $4, \S \S 7: 125-7: 212$.

35. Santa Fe Indus., Inc. v. Green, 430 U.S. 462 (1977). (1977).

36. Green v. Santa Fe Indus., Inc., 533 F.2d 1283 (2d Cir. 1976), rev'd, 430 U.S. 462

37. 430 U.S. at 471-80. Justice Brennan was the lone dissenter; see id. at 480 (Brennan, J., dissenting).

38. See Ralph C. Ferrara and Marc I. Steinberg, A Reappraisal of Santa Fe: Rule 10b-5 and the New Federalism, 129 U. PA. L. Rev. 263 (1980).

39. 430 U. S. at 477-80. See generally William L. Cary, Federalism and Corporate Law: Reflections Upon Delaware, 83 YaLE L.J. 663 (1974) (recommending the implementation of comprehensive federal fiduciary standards).

40. See discussion supra notes 14-18 and accompanying text.

41. 422 U.S. 66 (1975).

42. Id. at 78 :

First, is the plaintiff "one of the class for whose especial benefit the statute was enacted,"-that is, does the statute create a federal right in favor of the plaintiff? Second, is there any indication of legislative intent, explicit or implicit, either to create such a remedy or to deny one? Third, is it consistent with the underlying purpose of the legislative scheme to imply such a remedy for the plaintiff? And finally, is the cause of action one traditionally rele- 
tended to create a private remedy. ${ }^{43}$ Subsequent decisions further narrowed Cort's inquiry by focusing on statutory construction as the key determinant for whether a private right of action should be implied. ${ }^{44}$ As a consequence, the implication of private rights of action currently occurs with far less frequency than during the Borak era. ${ }^{45}$

The foregoing discussion provides a succinct analysis of the state of private securities litigation and, in particular, Section 10(b) and Rule 10b5 at the time that I joined the SMU faculty in 1989. During the 1990s to the present, the Supreme Court has continued to apply a restrictive interpretation to the scope of the Section 10(b) private right of action. In 1991, the Court, rejecting the doctrine of equitable tolling, adopted a one year/ three year statute of limitations for Section $10(\mathrm{~b})$ claims $^{46}$ that was subsequently nullified by Congress with its enactment of a longer statute of limitations (two year/five year). ${ }^{47}$

In my discussions with Alan in the aftermath of Supreme Court decisions, no decision stands out more in my memory than Central Bank of Denver ${ }^{48}$ decided in 1994. Prior to that decision, for several decades, aiders and abettors were within the Section 10(b) liability net. As Justice Stevens observed in his Central Bank dissent: "In hundreds of judicial and administrative proceedings in every circuit in the federal system, the courts and the SEC have concluded that aiders and abettors are subject

gated to state law, in an area basically the concern of the States, so that it would be inappropriate to infer a cause of action based solely on federal law?

43. Id. at 77-85; see California v. Sierra Club, 451 U.S. 287, 293 (1981) (stating that the four-prong standard specified in Cort remains the criteria through which to ascertain whether Congress intended to create a private right of action).

44. See, e.g., Transamerica Mortg. Advisors, Inc. v. Lewis, 444 U.S. 11, 15 (1979) ("The question whether a statute creates a cause of action, either expressly or by implication, is basically a matter of statutory construction.").

45. See, e.g., Va. Bankshares v. Sandberg, 501 U.S. 1083, 1102 (1991) ("The rule that has emerged in the years since Borak and Mills came down is that recognition of any private right of action for violating a federal statute must ultimately rest on congressional intent to provide a private remedy."); Bellikoff v. Eaton Vance Corp., 481 F.3d 110 (2d Cir. 2007) (holding that no implied right of action exists under specified provisions of the Investment Company Act); Sears v. Likens, 912 F.2d 889 (7th Cir. 1990) (joining overwhelming view of appellate courts in holding that $\$ 17(\mathrm{a})$ of the Securities Act does not provide a private right of action); Bennett v. United States Tr. Co. of New York, 770 F.2d 308 (2d Cir. 1985 ) (holding that no implied private right of action exists under $\S 7$ of the Securities Exchange Act). For further discussion, see 1 BROMBERG, supra note 4, §§ 2:54-2:101; Marc I. Steinberg, Securities Regulation: Liabilities and Remedies $\S 9.03$ (2014).

46. Lampf, Pleva, Lipkind, Prupis \& Petigrow v. Gilbertson, 501 U.S. 350 (1991) (holding that the applicable statute of limitations for private actions under $\$ 10(b)$ is one year after discovery of the facts constituting the violation within a three-year period of repose); see 6 BROMBERG, supra note 4, $\$$ 10:40-10:74.

47. 28 U.S.C. $\$ 1658$ (b), enacted as part of the Sarbanes-Oxley Act of 2002, provides that "a private right of action that ... involves a claim of fraud, deceit, manipulation, or contrivance in contravention of a regulatory requirement concerning the securities laws ... may be brought not later than the earlier of - (1) 2 years after the discovery of the facts constituting the violation; or (2) 5 years after such violation." See Merck \& Co. v. Reynolds, 559 U.S. 633 (2010) (construing the two-year discovery language of $\S 1658(\mathrm{~b})$ and holding that this period begins when a reasonably diligent person knows or should know of the facts constituting the violation, including the fact of the subject defendant's scienter).

48. Cent. Bank of Denver v. First Interstate Bank of Denver, 511 U.S. 164 (1994). 
to liability under $\$ 10(\mathrm{~b})$ and Rule $10 \mathrm{~b}-5 . " 49$ In a five to four decision, the Court, applying a strict statutory construction, rejected that view, stating: "Because the text of $\S 10$ (b) does not prohibit aiding and abetting, we hold that a private plaintiff may not maintain an aiding and abetting suit under $\S 10(\mathrm{~b}) . " 50$

Although not totally unexpected, the result in Central Bank was surprising to many practitioners and academicians. Indeed, the petitioner had conceded that aiding and abetting liability existed under Section 10(b) and had sought Supreme Court review, inter alia, on whether it could be held liable on the basis of recklessness rather than actual knowledge. ${ }^{51}$ Instead of addressing these issues, the Court sua sponte ordered the parties to address the question of the propriety of aiding and abetting liability under Section 10(b). ${ }^{52}$

The extent to which the Supreme Court confined the scope of Section 10 (b) and Rule $10 \mathrm{~b}-5$ within two decades after its decision in Hochfelder ${ }^{53}$ is shown by the fact that the plaintiffs in Hochfelder would not have been able to even institute that case two decades later due to two reasons. First, the statute of limitations would have run under the one year/three year time period adopted in Lampf;5 and, second, the defendant accounting firm was sued as an aider and abettor, and, hence, would not have been subject to private liability after Central Bank. 55

In the aftermath of Central Bank, the predominant issue was the primary liability exposure under Section 10(b) for collateral actors, such as attorneys, bankers, and consultants. In two subsequent decisions, the $\mathrm{Su}$ preme Court further confined the scope of Section 10(b) primary liability. In the first case, Stoneridge Investment Partners LLC v. Scientific-Atlanta, Inc. ${ }^{56}$ the Court under the facts alleged rejected the imposition of "scheme" liability against the subject defendants. Because the investing public did not have knowledge of the alleged illegal transactions engaged in by the defendants, the requisite element of reliance could not be

49. Id. at 192 (Stevens, J., dissenting) (emphasis in original).

50. Id. at 191. The Court's holding likely signified that the SEC as well could not bring enforcement actions against those persons who aided and abetted Section 10(b) violations. Congress resolved this issue by subsequently granting the Commission authority to pursue aiders and abettors. See 15 U.S.C. $\$ 78 t(e)$, Section 20(e) of the Securities Exchange Act (enacted pursuant to the Private Securities Litigation Reform Act of 1995).

51. 511 U.S. at 194 (Stevens, J., dissenting) ("Indeed, in this case, petitioner assumed the existence of a right of action against aiders and abettors, and sought review only of the subsidiary questions whether an indenture trustee could be found liable as an aider and abettor absent a breach of an indenture agreement or other duty under state law, and whether it could be liable as an aider and abettor based only on a showing of recklessness.").

52. Id; see 5 BRomberG, supra note 4, $\$$ 7:298-7:332.

53. Ernst \& Ernst v. Hochfelder, 425 U.S. 185 (1976), discussed supra notes $28-34$ and accompanying text.

54. Lampf, Pleva, Lipkind, Prupis \& Petigrow v. Gilbertson, 501 U.S. 350 (1991), discussed supra notes $46-47$ and accompanying text.

55. Cent. Bank of Denver v. First Interstate Bank of Denver, 511 U.S. 164 (1994), discussed supra notes $48-52$ and accompanying text.

56. 552 U.S. 148 (2008). 
shown. Accordingly, the Court reasoned, "[n]o member of the investing public had knowledge, either actual or presumed, of respondents' deceptive acts during the relevant times [and that] as a result, [plaintiffs] cannot show reliance upon any of respondents' actions except in an indirect chain that we find too remote for liability." 57 In rejecting the position held by a number of lower federal courts that the entering into by financial institutions and others of deceptive transactions as part of a scheme was within the scope of Section 10(b) primary conduct, ${ }^{58}$ the Supreme Court's holding signifies that persons who "behind the scenes" orchestrate a fraudulent scheme, where their actions are unknown to investors, are insulated from Section 10 (b) private liability..$^{59}$

The second decision, Janus Capital, ${ }^{60}$ focused on the reach of Rule 10b5(b) primary liability. That provision prohibits the making of material misrepresentations or half-truths in connection with the purchase or sale of a security. ${ }^{61}$ As viewed by the SEC and a number of lower courts, persons (such as attorneys) who drafted disclosure documents or who otherwise meaningfully participated in preparing the subject documents were "co-creators" and thereby within the reach of primary Section 10(b) liability exposure for materially false statements contained in such documents. ${ }^{62}$

Defining the word "make" in a restrictive manner, the majority in $J a$ nus Capital held that "the maker of a statement is the person or entity with ultimate authority over the statement, including its content and whether and how to communicate it." 63 Without such authority, the Court reasoned, one can "merely suggest" the contents of a statement, not in fact make the statement. ${ }^{64}$ Accordingly, without attribution of the

57. Id. at 159 .

58. See, e.g., In re Enron Sec. Derivative \& ERISA Litigation, 235 F. Supp. 2 d 549 (S.D. Tex. 2002); In re Enron Securities Derivative \& ERISA Litigation, 439 F. Supp. 2d 692 (S.D. Tex. 2006), rev'd 482 F.3d 372 (5th Cir. 2007); see also, 552 U.S. at 175 (Stevens, J., dissenting) ("I respectfully dissent from the Court's continuing campaign to render the private cause of action under $\$ 10(\mathrm{~b})$ toothless.").

59. For a critical assessment of the Court's decision, see, for example, Mark Klock, What Will It Take to Label Participation in a Deceptive Scheme to Defraud Buyers of Securities a Violation of Section 10(b)? The Disastrous Result and Reasoning of Stoneridge, $58 \mathrm{U}$. KAN. L. Rev. 309 (2010).

60. Janus Capital Grp., Inc. v. First Derivative Traders, 131 S. Ct. 2296 (2011).

61. 17 C.F.R. $\$ 240.10 \mathrm{~b}-5$ (b) (prohibiting, in connection with the purchase or sale of a security, "[t]o make any untrue statement of a material fact or to omit to state a material fact necessary in order to make the statements made, in the light of the circumstances under which they were made, not misleading").

62. See, e.g., SEC v. Wolfson, 539 F.3d 1249, 1251 (10th Cir. 2008) (stating that "when a non-employee consultant causes misstatements or omissions within periodic financial reports [to be] submitted to the Commission, knowing that those misstatements or omissions will reach investors, he can be held primarily liable under the anti-fraud provisions of the federal securities laws"); Brief of the SEC, Amicus Curiae in Klein v. Boyd, at 15, Nos. 97 1143, 97-1261 (3d Cir. 1998) (asserting that "a person who has the requisite scienter can be held liable as a primary violator of Section 10(b) of the Securities Exchange Act and Rule $10 \mathrm{~b}-5$ thereunder when he or she, acting alone or with others, creates a misrepresentation, whether or not the person is identified with the misrepresentation by name").

63. $131 \mathrm{~S}$. Ct. at 2302.

64. Id. 
statement to a collateral actor, the preparation, publication or drafting of a statement on another's behalf does not constitute the "making" of such statement by such collateral actor. ${ }^{65}$ The consequence of the Court's confining decision may well be that Section 10(b) primary liability is foreclosed with respect to those fraudsters who knowingly draft, advise, or otherwise integrally participate in the communication of outright lies to the investing public. ${ }^{66}$ As Justice Breyer wrote for the four-member dissent: "[W]here can the majority find legal support for the rule that it enunciates? . . I I can find nothing in $\$ 10$ (b) or in Rule 10b-5, its language, its history, or its precedent suggesting that Congress, in enacting the securities laws, intended a loophole of the kind that the majority's rule may well create." 67

Particularly with the trilogy of Central Bank, Stoneridge, and Janus Capital ${ }^{68}$ Alan expressed his disappointment with the Court's decisions that greatly confine Rule 10b-5's reach. By overruling decades of lower court precedent, applying unduly strict statutory construction, invoking wooden definitional terminology, and/or policy considerations directed at the danger of vexatious litigation, the Court has succeeded in significantly narrowing the scope of this vital right of action. Although far from a plaintiff's advocate, Alan lamented that these decisions unduly immunized bad actors from monetary liability at the expense of aggrieved investors. ${ }^{69}$

Section 10(b)'s continued vigor also has been challenged by Congress and, in particular, by the enactment of the Private Securities Litigation Reform Act of 1995 (PSLRA). ${ }^{70}$ In addition to "reforming" the institu-

65. Id. (recognizing that attribution of a statement (either expressly or implicitly from the surrounding facts and circumstances) constitutes "strong evidence" that such statement was made by the collateral actor to whom it is attributed).

66. The SEC takes the position that the drafter may be primarily liable under Rule 10b-5(a) or (c). See In re John P. Flannery, 2014 WL 7145625, at *13 (SEC Dec. 15, 2014) ("Accepting that a drafter is not primarily liable for 'making' a misstatement under Rule 10b-5(b), our position is that the drafter would be primarily liable under subsections (a) and (c) for employing a deceptive 'device' and engaging in a deceptive 'act.'"). Thus far, the courts have disagreed with the SEC. See, e.g., WPP Luxembourg Gamma Three Sarl v. Spot Runner, Inc., 655 F.3d 1039, 1057-58 (9th Cir. 2011) (and cases cited therein).

67. $131 \mathrm{~S}$. Ct. at 2307, 2311 (Breyer, J., dissenting). For commentary on Janus Capital, see, for example, 5 BRomberg, supra note 4, \$\$ 7:298-7:306.59; Marc I. Steinberg, Understanding Securities Law 340-42 (6th ed. 2014).

68. See discussion supra notes $48-67$ and accompanying text.

69. The Supreme Court decisions addressed in this article serve as key examples of the Court's restrictive approach to Section 10(b) and Rule 10b-5. Several other narrow decisions, not discussed in the text of this article due to space limitations, also illustrate this restrictive approach. For example, in the insider trading area, the Supreme Court adopted a rationale based on state law concepts of fiduciary duty. See, e.g., Dirks v. SEC, 463 U.S. 646 (1983); United States v. Chiarella, 445 U.S. 222 (1980). As a more recent example, overruling the approach undertaken by the lower federal courts, the Supreme Court held that Section 10(b) reaches only those transactions where the purchase or sale of a security is made in the United States or such purchase or sale involves a security listed on a U.S. exchange. See Morrison v. Nat'l Austl. Bank Ltd., 561 U.S. 247, 269-70 (2010). Congress has sought to nullify Morrison with respect to its application to government enforcement actions. See Section 929P of the Dodd-Frank Act (codified at 15 U.S.C. $\$ \$ 77 \mathrm{v}(\mathrm{c}), 78 \mathrm{aa}(\mathrm{b})$ )).

70. Pub. L. No. 104-67, 109 Stat. 737 (1995). 
tion, undertaking, and settlement of securities class actions ${ }^{71}$ this legislation directly impacts the scope of Section 10(b) in private litigation in two key ways: first, by enhancing the pleading fraud with particularity requirement of Rule 9(b) of the Federal Rules of Civil Procedure; ${ }^{72}$ and, second, by insulating forward-looking statements made by publicly-held companies from being actionable unless made with actual knowledge of their falsity (and further, if such statements are accompanied by meaningful cautionary disclosure, then deeming such statements to be not actionable as a matter of law)..$^{73}$ This legislation provides defendants with further avenues to seek and frequently obtain dismissal of lawsuits alleging violations of Section 10(b) and Rule $10 \mathrm{~b}-5$ at an early stage of the litigation. ${ }^{74}$

The "road" that Section 10(b) and Rule 10b-5 have taken since Professor Bromberg authored his seminal treatise in 1967 frequently has been arduous. Although this right of action remains as the principal provision invoked by securities class action plaintiffs, many hurdles must be traversed. I believe that Professor Bromberg felt that many of these obstacles were well-placed, such as the Blue Chip standing requirement, the Hochfelder scienter standard, and the Santa Fe mandate that a disclosure deficiency must be shown. On the contrary, Professor Bromberg, in my opinion, believed that certain other Supreme Court decisions were poorly reasoned and made bad public policy. Among these decisions is Central Bank of Denver that foreclosed aiding and abetting liability in Section 10 (b) private actions as well as the Stoneridge and Janus Capital decisions that further restricted aggrieved plaintiffs in their quest to seek relief against collateral actors. ${ }^{75}$

Professor Alan R. Bromberg had an illustrious academic career. For half a century, he was one of the preeminent scholars in the world in the business enterprises and securities law fields. He also was an exceptional

71. These reforms are aptly described in Private Securities Litigation Reform Act, Joint Explanatory Statement of the Committee of Conference (1995).

72. See 15 U.S.C. $\$ 78 \mathrm{u}-4(\mathrm{~b})$, Section $21 \mathrm{D}(\mathrm{b})$ of the Securities Exchange Act, enacted pursuant to the PSLRA, construed in, Tellabs, Inc. v. Makor Issues \& Rights, Ltd., 551 U.S. 308, 321 (2007) ("Under the PSLRA's heightened pleading instructions, any private securities complaint alleging that the defendant made a false or misleading statement must: (1) 'specify each statement alleged to have been misleading [and] the reason or reasons why the statement is misleading,' and (2) 'state with particularity facts giving rise to a strong inference that the defendant acted with the required state of mind' ...." (quoting $\S 78 \mathrm{u}-$ 4(b))).

73. 15 U.S.C. $\$ 77 \mathrm{z}-2$, Section 27 A of the Securities Act; 15 U.S.C. $\$ 78 \mathrm{u}-5$, Section 21E of the Securities Exchange Act. See Asher v. Baxter Int'l, Inc., 377 F.3d 727, 729 (7th Cir. 2004) (quoting 15 U.S.C. $\$ 77 z-2(c)(1)(A)(i)$ ) ("The statutory safe harbor forecloses liability [regardless of the defendant's state of mind] if a forward-looking statement is accompanied by meaningful cautionary statements identifying important factors that could cause actual results to differ materially from those in the forward-looking statement" "). Accord Slayton v. Am. Express Co., 604 F. 3d 758, 769, 773 (2d Cir. 2010).

74. See Marc I. Steinberg, Pleading Securities Fraud Claims-Only Part of the Story, 45 Loy. U. CHI. L.J. 603, 606 (2014) (stating that statistics show that securities class actions are regularly dismissed by federal district courts and that in $201247 \%$ of motions to dismiss were granted).

75. See 5 BromberG, supra note 4, \$§ 7:298-7:332. 
person, with kindness, humility, loyalty, courtesy, and empathy among his many attributes. I was fortunate to have him as my good friend. I thank you and miss you Alan. 